\title{
RMIT University
}

\section{Lucinda Strahan}

\section{Not a memoir: an essay}

\section{Biographical note:}

Lucinda Strahan is a writer of essay, journalism and experimental nonfiction. She has published in major Australian newspapers, magazines and journals and her hybrid literary-visual works have been published in Defunctmag 2 and exhibited in 'The Swapshop Laboratory' (NonfictionNow 2012) and 'Writing Naked' (Melbourne Writers' Festival 2009). Lucinda is a lecturer in the Professional Communication program, and a researcher in the non/fictionLab at RMIT University. She is a PhD candidate at the University of Wollongong.

Keywords:

Essay - Memoir - Genre experimentation - Spatial autobiography 


\section{Some stories demand to be told, almost physically.}

People always say that don't they? That you can write your way out of pain, trauma, misery. That it can be spun into airy gold on the page.

'Language writing its way out of difficulty,' critic Anatole Broyard described it as he wrote through and to the end of his battle with prostate cancer. Like Virginia Woolf exorcising memories of her mother, writing To the Lighthouse in 'a great, apparently involuntary rush,' as she described it, 'my lips seemed syllabling of their own accord as I walked. Who blew the bubbles? Why then? I have no notion. But I wrote the book very quickly. And when it was written I ceased to be obsessed by my mother. I no longer hear her voice; I do not see her.'

Ah! Yes, this catharsis. This promise.

That was the payoff, I always told myself. Each time I glued my mind back together with those little blue antipsychotic tranquilisers, the old generation ones that can give you tardive dyskinesia (an irreversible muscle tic usually of the mouth). That was the payoff I always said when I was at my worst, and gave up something else I wanted really badly, for the crippling anxiety of wanting it. The suggestion was persistent; it was all leading somewhere.

'I wonder what you're going to do with it all,' my first psychiatrist would ask. Maybe I was 19, 20, 21?

This was the idea: that it all would be redeemed one day, this suffering would all come good and a stunning sense would be made.

\section{In a book! A Book With My Name On It.}

Just before the tipping point came there it was, a bright flash of recognition. My father had died suddenly from cancer months before. Things seemed to be coming to a head. 'Here it is,' I thought, 'the great climax to my epic of suffering.'

Clear through the grip of misery and grief and tranquilizers major and minor the narrative turn was obvious. There would be a reckoning, a true test of will and talent borne out on the page. And at last! I would be held, I would be held together between the covers of My Book.

Here it comes

Here it comes

Here it comes

Here it

comes. Here comes my nineteenth nervous breakdown. I have too much material. Collapse and recovery is a ready-made, best-selling storyline and I haven't just done it once! I've done it over and over and again -

It was such a relief to stop work and I was euphoric all the way home on the tram and up the stairs and into our apartment. I had raised the white flag. I had fired off a phalanx of emails, dropped all responsibilities and made a run for it. I felt light, elated, and clear 
as a bell as I stepped through the door and dropped my bag on the kitchen table. But then suddenly I knew something. Quite clearly I said to myself, 'This is not going to last. This high is not going to last.' I put some lasagna in the oven knowing that I needed to eat and that very soon preparing dinner would be out of the question.

I ran a bath and put my laptop on a little table so I could watch something online but as soon as I lifted the lid the emails started streaming in bing! bing! bing! bing! in they came from all those people I had just let down, those ones who now knew how hopeless and weak and no good I am because I can never get anything right, how dumb and stupid I am for ever trying, hopeless, trying to take on demands and rewards and responsibilities, that's not for me - worthless, weak, idiot, my mind slipped and gave up the last little bit of traction that had been holding me in the adult world, and I was back, back, back in the filthy rabbit run.

$$
\begin{gathered}
\text { day } \\
\text { diazepam } \\
\text { lorazepam } \\
\text { temazepam } \\
\text { alprazolam } \\
\text { quetiapine } \\
\text { zopiclone } \\
\text { zolpiden } \\
\text { night }
\end{gathered}
$$

But it won't be all crying in the bath. My Book will be wry, it will ease the way for the reader with clever asides and dark humour. I will make skipping songs out of sedatives and jokes at my own expense. I will quicken the pace with sharp language like those old American blags who drank themselves to death. Dorothy Parker's deco banter is so much more entertaining than contemporary psychobabble. Capote's 'mean reds' sounds a lot better than 'Generalised Anxiety Disorder'.

'Everything's kind of terrible isn't it? I can’t help getting sunk,' Parker's suicidal Big Blonde Hazel Morse tells her date, Art.

'Ah sunk my eye,' he tells her, 'What have you got to be sunk about?'

Facing herself in the mirror holding the vials of veronal tablets on which she will overdose, Hazel feels giddy with the 'quick excitement of one who is about to receive an anticipated gift'. She raises her glass of water to her reflection, 'Well, here's mud in your eye,' she says.

I will not use the word 'depression', that insipid, slug of a word as William Styron called it in his own Memoir of Madness. He suggested 'brainstorm' but I don't think that's much good either actually. 'Depression' describes nothing and doesn't really 
account for the kind of frantic collapses I experience. I don’t feel like a dip in a line on a graph, I feel shattered and hopeless and debilitated.

'You're afraid and you sweat like hell, but you don't know what you're afraid of. Except something bad is going to happen, only you don't know what it is.'

'Who said that?' my psychiatrist asks me.

'Holly Golightly,' I tell him. 'That paragon of female self-contempt who still passes for cute.'

'What are your symptoms?' he asks me.

'I'm out of chamomile tea,' I tell him. 'I take the pot and cups into the bath with a small bottle of lavender essential oil looking for comfort. I'm re-reading Peter Carey novels; I know everything about all the listener competitions on ABC radio because that's all I do all day. I have no sex drive and the whole house smells like dirty laundry and catastrophe.'

'Cute,' he says.

My psychiatrist's rooms are in a draughty old house in the inner-city, across the road from a cemetery. I see him weekly. I'll call him The Shaman, to protect our professional relationship of course and because he's more than just a doctor. He's a doctor-healer, a laconic, sweary kind of doctor-healer. He meditates every day. He learnt this from a high Tibetan lama who came to Australia in the 1980s and runs a centre up the road. The Shaman says it's all fiction. The self is just stories we tell and retell ourselves all the time. He writes me prescriptions and teaches me how to get to know the stories.

'Where do you feel it in your body?' he always asks me.

'Breathe,' he always says.

When I am well enough I ride my bike to appointments. I had a bicycle-themed dream about him once. It was not set in his rooms - it was maybe his home? Who knows, it was somewhere with a back yard and there were two crazy bicycles and some vintage cars - an old Porsche, a kind of, Karmann Ghia type of thing, and a Chevrolet, or Mustang maybe? And then these strange bicycles, one was a Lamborghini and one was a Ferrari. The Shaman gave me the Ferrari bicycle to ride. It was very difficult because there was so little to hold on to - imagine a drawing of a bike by Salvador Dali that would have a very tall seat very far away from the wheels and then a very long, high pole leading to a very small handlebar. I didn't really want to borrow it, because it looked so tricky and also it seemed like something quite expensive and personal to The Shaman - I wasn't sure if I should be taking it, but he just laughed and said, 'Go, go ahead.’ I took it but I was scared. It was very, very difficult to balance on.

I told The Shaman about the dream and he said, 'Well, I don't think that needs much interpretation.' 


\section{Maybe start at the start, on the surface.}

I make my way up Collins Street toward a set of anonymous brass doors with very shiny handles. As I go, I feel the sound of my high-heels turn from a hollow scratch to a solid 'glock' as if the very pavement under my feet is lined with a layer of dark green felt like the display cases and jewellery boxes in the shop windows. At the slim doors sandwiched between a jeweller and a new Prada store, I step into a vestibule where an attendant sits waiting to sign me in. She directs me to the cloakroom, an unattended anteroom behind the lift that is furnished with a Victorian screen, a chaise-longue, a dressing-table and a full-length mirror. I check my hair and my lipstick and tuck in my shirt (it's silk and it keeps slipping).

Anne escorts me to the lift. 'Maybe in the Green Room,' she says, 'let's go and have a look shall we?'

On her visit to Australia in 1898, British sociologist and labour reformer Beatrice Webb (known less well by her title Baroness Passfield) complained bitterly about 'the nicelymannered but idle, empty headed young women' of the Australian ruling classes who were 'uncommonly inferior to the men.' 'Certainly these colonial women are in an unpleasant stage of development,' she wrote in her diaries. Dr Alexander Morrison, Headmaster of Scotch College, the Melbourne boys' school that would educate Australian prime ministers and leaders of industry, is on the record at the time as agreeing with the fearsome diarist, that the well-to-do women were 'the least worthy product of Australia.'

We go down a floor and Anne slides the antique lift door open onto a room decorated in shades of forest, laurel, mint and moss. 'No it doesn't look like she's in here,' she says. 'Let's have a look in the Dining Room. If she's not there she might be in the library.'

The 'least worthy product of Australia' would certainly mean much less worthy than the alluvial gold that had just been discovered in Kalgoorlie, Western Australia, at the time of Webb's visit. But also less worthy than the 'fine total' of 276,119 mutton carcasses exported by the year 1904, which, 'when one compares this with the first output in 1896 of 2848 carcasses,' noted the South Australian Department of Agriculture, 'one is impressed.'

When we get to the Dining Room my mum is sitting on one of the chintz sofa settings underneath the windows. 'You look smart,' she says. Yes I do. It's not an accident.

I sink into a plumped-up sofa and run my fingers along its upholstered arm taking in the sheen of the greens, pinks and creams. There are two shades of mint on the walls and another in the carpet and I think, 'this room is also very green, why do they call the other one The Green Room?' But even though I’ve been here many times before, I don't know the answer to this or any of the other mysteries of this place. Now my shameful curiosity must be smuggled in. They're in here somewhere. Clues. Hiding in these mint condition rituals of miserable respectability.

A maid comes over and asks if we would like a drink. I would say waitress, concierge, 
hostess but it would not be quite right. She's wearing a shapeless black waistcoat a white shirt and terribly sensible shoes and my mother calls her by her first name while she says, 'Yes, Mrs -

'A gin and tonic please,' I say, and she says, 'Certainly.'

Momentarily, the drinks come on a tray. First, two white monogramed coasters and a little silver pot filled with four cheese biscuits and two dainty breadsticks is set before us on the low polished table. Then the tumblers with the spirits poured over some ice are set on the coasters and the mixers are poured from elegant single-serve bottles - not too much though - with the rest set aside next to the glass.

'Cheers.'

Something strange comes into focus. Have you seen Terry Gilliam's Brazil? Do you remember a minor character called Shirley? She's the long-suffering daughter of Mrs Terrain, the loony dowager who's always having 'a little complication' with her plastic surgery. In Gilliam's absurdist dystopia, Shirley is a well-dressed gimp, gagged by orthodontic headgear and bound to the wheelchair of her mother who is intent on setting her up with the film's protagonist, Sam Lowry.

When I first watched Brazil as an undergraduate it wasn't a fully formed thought, or a conscious storing away of this image - it wasn't a knowing idea that I had about Shirley, this gross caricature of stifled Anglo femininity, just somewhere in the back of my mind I clocked it, like, 'ha ha, brilliant, yes.'

Now sitting here, in my silk shirt and my ironed slacks looking at my gin and tonic set out on the table, I remember it. I'm sure you don't, but I remember it.

There is no one else here, just us and the sound of the grandfather clock, and the muffled rumbling of trams outside and Bing Crosby playing very softly on the stereo.

\section{Sitting there on the couch in The Shaman's office looking at the cork coasters on the table in that same spot I always look at when I'm trying to avoid his eye.}

There's a tightness in my chest and across my forehead. There's a weight on my chest. For months I have been walking around with this stifling, leaden feeling.

'Breathe,' he says.

I start crying. 'Ah, good!' he raises his eyebrows and smiles.

'Where do you feel it in your body?' he says.

This thing I am not meant to be doing, these stories running through my fingers and onto the page. It feels like that sometimes doesn't it, it feels like too much.

Like old Stendhal on the steps at Santa Croce: 'the palpitations of the heart, what in Berlin they call "nerves”.' My head feels rushed, my muscles give way, I kind of feel high and then I have to shit - this happens. I see the stories and I go to write them down and this happens.

I feel something hot and hard, and dry like a rock in my mouth. 
'I feel a skewer running through my cheeks,' I tell him.

'That's interesting,' he says.

'Breathe,' he says.

'I can't live like this,' I say.

'Yes you can. You are living like this,' he tells me.

'I don’t want to live like this,' I say.

'Like what?' he says.

'In bits,' I say, 'everything in bits.'

'How big are they?' he says. 'Are they heavy or light? Can you pick them up?'

Sitting in that office with the cork coasters on the table I always look at -

\section{Whose idea was it? Who fucking said that?}

That if I wrote a book from start to finish, with my name on it, that I'd never feel like a shithead ever again? Who fucking said that?

That I could put myself back together in a story that made sense?

There are so many things. Feelings, images, sensations. Anger comes in bright splinters, without a middle and an end.

I like it.

I am not who I thought I would be. There are so many things.

Gaps and silences.

Rhythms.

Resolution is absurd.

These stories. 


\section{Research Statement}

\section{Research background}

A movement of international critics and writers have called for experimentation toward new forms that liberate 'creative nonfiction' from its position as a beset subset of journalism, and the literary poor-cousin of the novel (Shields 2010), proposing it instead as ground for a new experimental literature of 'the real'. 'What distinguishes creative nonfiction as a genre, we propose, is not only the truth-value of the writing. It's the way in which the raw material of "reality" is transformed into literary art' (Singer \& Walker 2013). These critics and writers revel in nonfiction's subversive in-betweenness and generic lack of definition, the 'perplexing ambiguity ... [and] the inherent resistance embodied in the close proximity and conjoining of the two parts', 'non' and ‘fiction’ (Carlin \& Rendle-Short 2013).

\section{Research contribution}

The work 'not a memoir: an essay' contributes to this experimentation by playing between the genres of memoir and personal essay using the tension within autobiographical writing between the temporal and the spatial: 'between narrative (chronological sequence and the course of a life over time as modes of explanation) and portrait (elaborations of the self writing in the present)' (Broughton 2007).

\section{Research significance}

The work forms part of a wider research project situated within this community of practice and international debate. Its significance lies in its contribution to an emerging hybrid form that might be known as 'spatial autobiography' that writes the self in space, using experimental methods such as fragmented narrative, image and design writing, and found and sampled texts.

\section{Works cited}

Broyard A 1992 Intoxicated by my illness: and other writings on life and death, Ballantine Books, New York

Capote T 2012 Breakfast at Tiffany’s, Vintage International, New York

Carlin David and Francesca Rendle-Short 2013 'Nonfiction now: a (non)introduction’, TEXT special issue 18: http://www.textjournal.com.au/speciss/issue18/Carlin\&RendleShort.pdf (accessed 14/7/16 )

Gilliam T 1985 Brazil [Motion picture], Embassy International Pictures, England

Parker D 2007 [1929] 'Big Blonde’, The Collected Dorothy Parker, Penguin, London

Shields D 2010 Reality Hunger: a manifesto, Alfred A. Knopf, New York

Singer M and N Walker (eds) 2013 Bending genre: essays on creative nonfiction, Bloomsbury, London and New York

Styron W 1992 Darkness visible: a memoir of madness, Vintage, New York 
Woolf V 1976 [1939] 'A Sketch of the Past', Moments of being, Vintage, New York 